\title{
Evaluasi Perancangan Sistem Informasi Pengelolaan Pengarsipan Surat Berbasis Web
}

\author{
${ }^{1}$ Erwin Fathullah, ${ }^{2}$ Awalludiyah Ambarwati \\ ${ }^{1,2}$ Program Studi Sistem Informasi, Fakultas Ilmu Komputer, Universitas Narotama
}

\author{
Alamat Surat \\ Email: erwinfathullah98@gmail.com
}

\author{
Article History: \\ Diajukan: 17 Agustus 2020; Direvisi: 31 Oktober 2020; Accepted: 31 Oktober 2020
}

\begin{abstract}
ABSTRAK
Dalam sebuah organisasi, penggunaan teknologi informasi diantaranya sistem pengarsipan surat masuk surat keluar sangat penting untuk menunjang perkembangan organisasi dari sisi kegiatan operasional, salah satu organisasi yang membutuhkan sistem infromasi pengarsipan surat yaitu Lembaga BS di Kabupaten Sidoarjo. Penyimpanan arsip secara fisik dapat menimbulkan kerusakan, kendala dalam proses pencarian dan memerlukan tempat penyimpanan yang besar. Pada penelitian ini akan dibuat suatu perancangan sistem informasi pengersipan surat menggunakan metode berorientasi objek dan pemodelan Unified Modeling Language (UML) dan evaluasi menggunakan metode Traceability yang dapat memberikan kemudahan dalam lembaga. Hasil dalam penelitian ini yaitu, proses bisnis model yang ada saat ini dan yang diusulkan, analisis persyaratan yang mencakup 19 fitur, 15 persyaratan fungsional, 4 persyaratan non-fungsional, delapan aktor, dan sepuluh use case. Hasil rancangan sistem terdiri dari analisis use case diagram, activity diagram, rancangan sequence diagram dan rancangan user interface. Dengan adanya perancangan sistem informasi pengarsipan ini diharapkan kedepannya dapat membantu urusan pendataan surat masuk dan surat keluar serta mempermudah proses pendisposisian surat yang ada di Lembaga BS.
\end{abstract}

Kata kunci: Unified Modeling Language; Traceability; Pengarsipan surat; use case

\begin{abstract}
In an organization, information technology, including filing systems for incoming and outgoing mail, is significant in supporting organizational development in terms of operational activities. One of the organizations that require a letter filing information system is the BS Institute in Sidoarjo Regency. Storage of physical archives can cause damage, obstacles in the search process and requires ample storage. In this research, an archive information system design will be made using an object-oriented method and Unified Modeling Language (UML) modeling and evaluation using the Traceability method to provide convenience in the institution. This study's results are the current and proposed business process model, requirements analysis, which includes 19 features, 15 functional requirements, four non-functional requirements, eight actors, and ten use cases. The system design results consist of use case analysis, activity diagrams, sequence diagram designs, and user interface designs. With the archiving information system's design, it is expected that in the future, it will be able to assist in the data collection of incoming and outgoing letters and facilitate the process of submitting letters in Institution BS.
\end{abstract}

Keywords: Unified Modeling Language; Traceability; filing systems; use case

\section{PENDAHULUAN}

Lembaga BS merupakan salah satu lembaga negara yang diperbolehkan menurut UU No 43 Tahun 2009 (Mahmudah et al., 2019), untuk memiliki beberapa sistem seperti Sistem Kepegawaian, 
Akuntansi, Inventory, Kearsipan dan lain-lain. Salah satu bagian sistem informasi yang menjadi pokok perhatian pada sebuah lembaga adalah sistem kearsipan. Kegiatan penyimpanan arsip mempunyai suatu prosedur agar teratur dan rapi. Prosedur penyimpanan surat masuk dan surat keluar, meliputi pemeriksaan, mengindeks, menyortir, dan meletakkan (Irmawati \& Indrihapsari, 2014). Banyak media dan dokumen yang diciptakan untuk memudahkan manusia untuk mencari, menyimpan dan menyebarkan informasi tersebut. Umumnya dokumen-dokumen tersebut dikenal sebagai arsip (Hatta et al., 2019).

Selama ini pengelolaan proses bisnis data kearsipan surat masuk dan keluar yang ada di pada Lembaga BS masih banyak mengalami keluhan dari setiap divisi untuk pengelolaan kearsipan surat masuk dan surat keluar dalam hal mencari informasi, menerima surat masuk, surat keluar, disposisi surat, adapun prosedur yang dilakukan adalah prosedur yang diterapkan dalam pengolahan data arsip surat masuk dan surat keluar yang ada pada Lembaga BS terkadang masih menyulitkan pegawai jika harus mencari suatu surat masuk atau keluar yang dibutuhkan dikarenakan banyak nya arsip yang ada selama bertahun-tahun lamanya, dikarenakan tidak adanya informasi peletakan yang lebih jelas pada rak lemari. Sering terjadi kehilangan dokumen penting karena tidak ada tempat untuk menyimpan dokumen dengan aman.

Penelitian ini menggunakan Object Oriented Analysis Desain (OOAD) dimana pendekatan yang dilakukan untuk mengembangkan suatu sistem yang baru dan responsif terhadap lingkungan yang sering berubah (Dewati et al., 2019). dan pemodelan Unified Modeling Languange (UML) merupakan salah satu alat bantu yang sangat handal di dunia analis dan perancangan sistem informasi yang berorientasi obyek (Object Oriented) (Setiawan \& Yanuarti, 2016). UML sendiri menyediakan Bahasa pemodelan visual yang memungkinkan bagi pengembang sistem untuk membuat cetak biru (blue print) dalam bentuk yang mudah dimengerti dan bisa membagikan rancangan sistem pengarsipan dengan yang lain. Evaluasi menggunakan metode Traceability merujuk pada kemampuan untuk mendeskripsikan dan mengikuti perkembangan kebutuhan sistem dari awal hingga deskripsi kebutuhan akhir sistem (Safitri et al., 2018). Traceability diakui sebagai faktor penentu keberhasilan dalam pengembangan perangkat lunak dan kualitas penting dari sistem perangkat lunak yang dirancang (Esparteiro Garcia \& C. R. Paiva, 2016).

Penelitian terkait tentang sistem informasi kearsipan maupun pendataan surat masuk dan surat keluar sudah pernah dilakukan, seperti penelitian yang telah dilakukan (Rahayu \& Hana, 2016) penelitian tersebut menggunakan metode pengumpulan data dan analisis data, pada penelitian tersebut actor use case yang digunakan hanya dua, admin dan user. Penelitian terkait selanjutnya dilakukan Afifah Qonita pada tahun 2018 (Qonita et al., 2018), penelitian tersebut juga menggunakan metode evaluasi Traceability hasil dari penelitian tersebut didapatkan jika fase perancangan yang diuji menggunakan matrik Traceability bisa dilacak dan memiliki kode unik. Harapan pada penelitian yang dilakukan dapat membangun sebuah rancangan sistem informasi pengelolaan pengarsipan surat dengan menggunakan pendekataan OOAD dan pemodelan UML dengan aktor didalam sistem terdapat lebih dari dua aktor yang lebih banyak dari penelitian sebelumnya.

Penelitian ini ditulis dengan alur yang pertama adalah tahap Analisis permasalahan dimana pada tahap ini menganalisis permasalahan yang ada pada Lembaga, tahap selanjutnya pengumpulan data melalui media wawancara dan file hasil wawancara berupa rekaman audio yang nantinya dapat membantu dalam pengumpulan data. Ditahap identifikasi kebutuhan dan perancangan sistem saling berhubungan karena identifikasi kebutuhan merupakan tahap untuk merancang sebuah sistem. Tahap evaluasi yaitu tahap mengevaluasi rancangan sistem yang dibuat dengan menggunakan metode yang sudah ditentukan dan yang terakhir tahap kesimpulan dari semua tahapan penelitian disimpulkan menjadi satu kesatuan.

\section{METODE}

Perencanaan alur penelitian merupakan serangkaian tahapan untuk menyelesaikan penelitian ini. Tahapan penelitian terdiri dari enam tahapan seperti digambarkan pada Gambar 1. Tahap pertama 
Analisis Permasalahan yang kedua pengeumpulan data, ketiga identifikasi kebutuhan, keempat perancangan sistem, kelima evaluasi dan yang terakhir adalah kesimpulan.

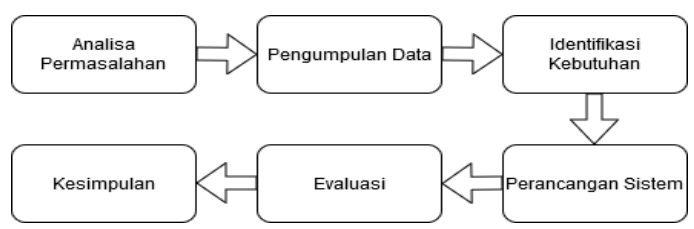

Gambar 1. Tahapan Penelitian

\subsection{Analisis Permasalahan}

Menganalisis permasalahan apa yang sedang dialami dalam hal kearsipan surat -menyurat. Berdasarkan hasil analisis penulis terdapat beberapa bagian yang memang masih belum terkomputerisasi dan masih di lakukan secara manual.

\subsection{Pengumpulan Data}

Data yang digunakan berupa rekaman wawancara berupa file audio yang membahas tentang fitur- fitur apa saja yang ingin dibuat pada sistem yang berjalan nantinya, serta bagaimana prosedur penerimaan surat masuk dan surat keluar yang ada pada Lembaga selama ini. Untuk pertanyaan yang diajukan ketika wawancara bisa dilihat pada Tabel 1.

Tabel 1. Form Wawancara

\begin{tabular}{ll}
\hline No & \multicolumn{1}{c}{ Pertanyaan } \\
\hline $\mathbf{1}$ & Bagaimana prosedure untuk penerimaan surat masuk dan surat keluar? \\
\hline $\mathbf{2}$ & Bagaimana sarana penyimpanan arsip surat selama ini? \\
\hline $\mathbf{3}$ & Kendala seperti apa yang sering terjadi ? \\
\hline $\mathbf{4}$ & Untuk sistem, ingin sistem kearsipan seperti apa? \\
\hline $\mathbf{5}$ & Apa saja Fitur - fitur yang dibutuhkan atau diinginkan dalam sistem kearsipan? \\
\hline
\end{tabular}

\subsection{Identifikasi Kebutuhan}

Menjelaskan kebutuhan awal dalam pembuatan system yang ingin di rancang. Pengguna membutuhkan sebuah aplikasi yang dapat membantu dalam proses pengelolaan surat masuk dan keluar serta pembuatan laporan. Berdasarkan hasil wawancara pada tahap pengumpulan data didapatkan sebuah usulan dalam hal perancangan sistem informasi kearsipan kedepannya, usulan tersebut bisa dilihat pada Tabel 2 .

Tabel 2. Hasil Wawancara

\begin{tabular}{ll}
\hline $\mathbf{N o}$ & \multicolumn{1}{c}{ Fitur-Fitur Sistem } \\
\hline $\mathbf{1}$ & Fitur login untuk setiap divisi dan Kepala Lembaga \\
\hline $\mathbf{2}$ & Fitur tambah data surat masuk \\
\hline $\mathbf{3}$ & Fitur tambah data surat keluar \\
\hline $\mathbf{4}$ & Fitur disposisi surat \\
\hline $\mathbf{5}$ & Fitur ubah dan hapus surat masuk dan surat keluar \\
\hline $\mathbf{6}$ & Fitur untuk mencetak laporan surat masuk dan surat keluar \\
\hline $\mathbf{7}$ & Fitur untuk ubah password \\
\hline $\mathbf{8}$ & Fitur untuk tambah user \\
\hline $\mathbf{9}$ & Fitur untuk pencarian surat \\
\hline
\end{tabular}


$\mathbf{1 0}$ Fitur untuk laporan setiap ada update data

11 Fitur untuk Administrator sistem

12 Fitur cetak laporan per periode, minggu dan bulan

13 Fitur lihat arsip data surat masuk dan surat keluar

\subsection{Perancangan Sistem}

Tahap Perancangan Sistem adalah merancang sistem secara rinci berdasarkan hasil analisis sistem yang ada, sehingga menghasilkan model sistem baru yang diusulkan, dengan disertai rancangan database (Setiawan \& Yanuarti, 2016). Alat bantu untuk memodelkan sistem yang diusulkan adalah diagram UML yaitu Use Case Diagram, activity diagram, sequence diagram dan User Interface.

\subsection{Evaluasi}

Evaluasi pada tahap penelitian kali ini adalah mengevaluasi setiap rancangan sistem apakah sudah sesuai dengan kebutuhan metode yang digunakan adalah metode traceability, traceability dapat dibuat setelah semua persyaratan sudah teridentifikasi. Tabel tersebut menghubungkan persyaratan yang mengidentifikasi satu atau lebih aspek dari sistem (Dewati et al., 2019).

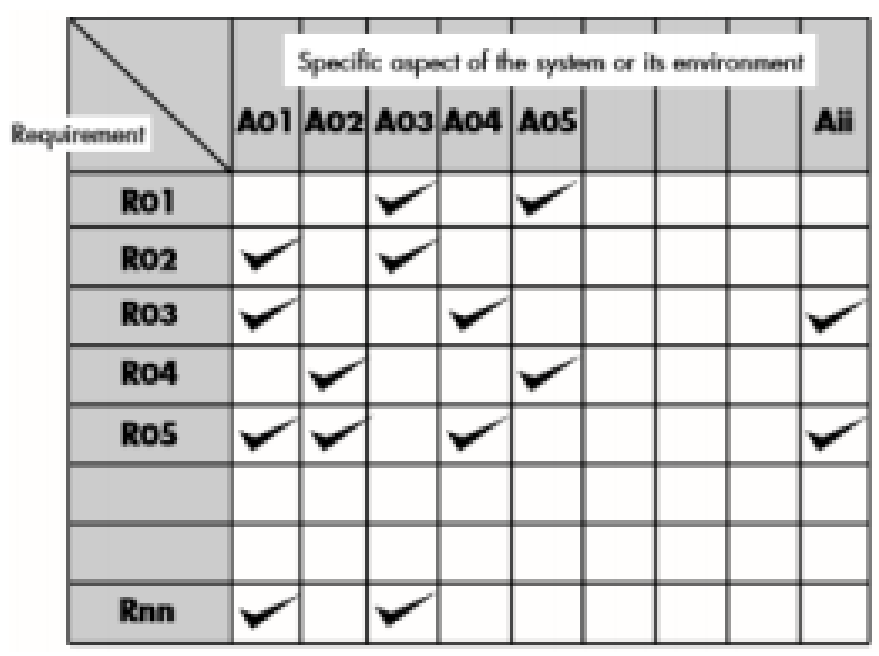

Gambar 2. Tabel Traceability (Dewati et al., 2019)

\subsection{Hasil dan Kesimpulan}

Setelah semua langkah sudah dilakukan dapat ditarik hasil dan kesimpulan yang dapat membantu penelitian selanjutnya guna untuk mengembangkan perancangan sistem informasi kearsipan yang sudah di buat.

\section{HASIL DAN PEMBAHASAN}

Bagian ini membahas hasil dari penelitian dan pada waktu yang sama juga memberikan pembahasan dan yang komprehensif. Hasil penelitian dapat disajikan menggunakan gambar, grafik, tabel, dan lainnya yang membuat pembaca dapat memahami hasil penelitian dengan mudah. Pembahasan dapat dibuat dengan menggunakan beberapa sub-bab.

\subsection{Hasil}

Hasil dari penelitian penulis adalah sebuah rancangan sistem informasi kearsipan surat disebuah organisasi pemerintahan, dengan menggunakan metode untuk mengevaluasi perancangan system yang sudah dibuat. 


\subsection{Usecase Diagram}

Usecase diagram sistem informasi pengelolaan pengarsipan surat digunakan untuk menjelaskan kegiatan dari aktor yang dapat dilakukan oleh pegawai staff divisi, Arsip dan Kepala Lembaga pada sistem.

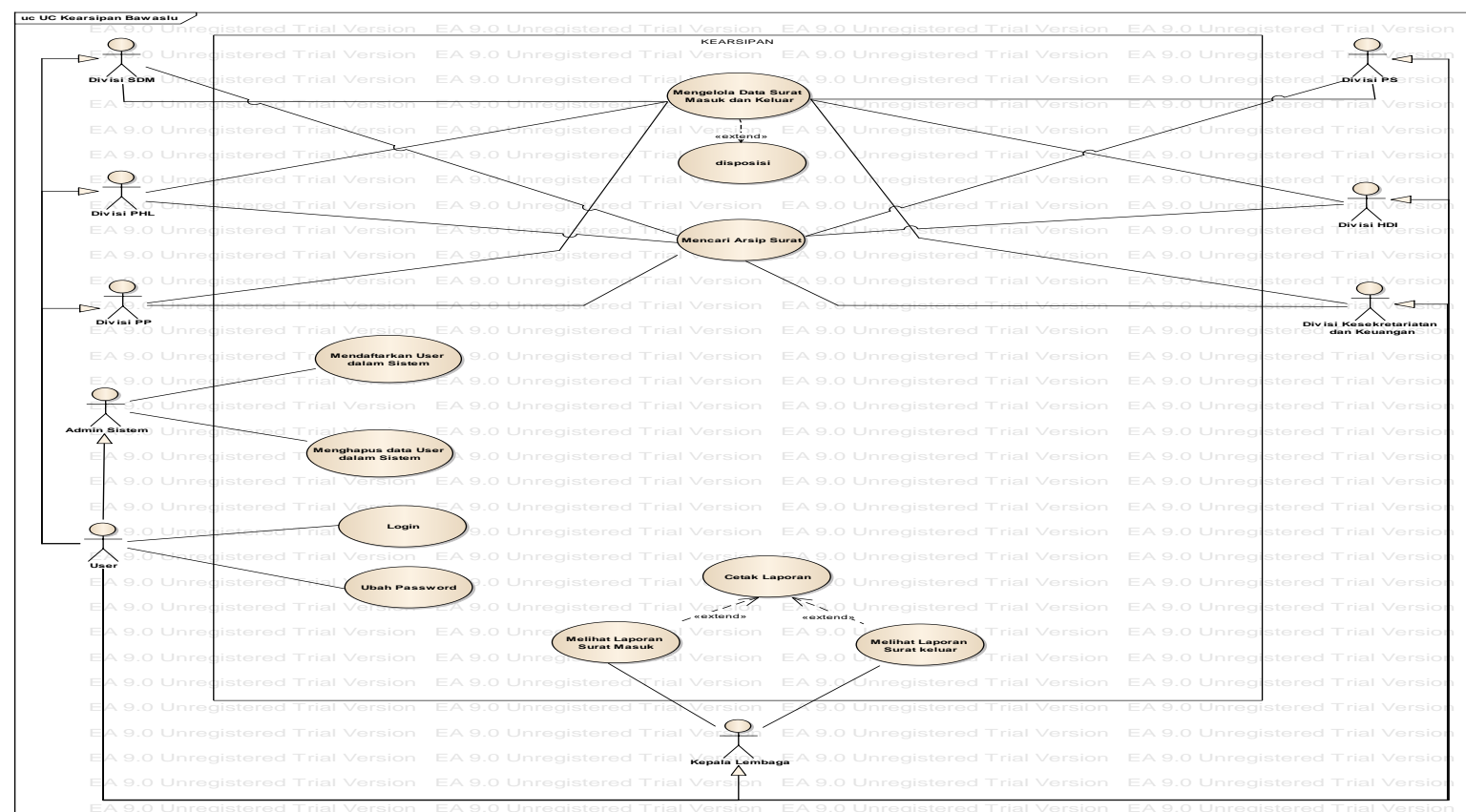

Gambar 3. Usecase Diagram Kearsipan di Lembaga BS

Pada Gambar 3 dijelaskan Aktor-aktor yang terlibat kedalam sistem, ada delapan aktor yang terlibat kedalam use case diantaranya, Administrator, Kepala Lembaga, Divisi SDM, Divisi PP, Divisi HDI, Divisi PHL, Divisi PS, Divisi Kesekretariatan dan Keuangan.

\subsection{Activity Diagram}

Activity diagram digunakan untuk menggambarkan alur kerja (work flow) sebuah Proses bisnis dan urutan aktivitas pada suatu proses (Setiawan \& Yanuarti, 2016). Pada Gambar 4 adalah hasil rancangan activity diagram yang sesuai dengan kebutuhan sistem yang dibutuhkan di Lembaga.

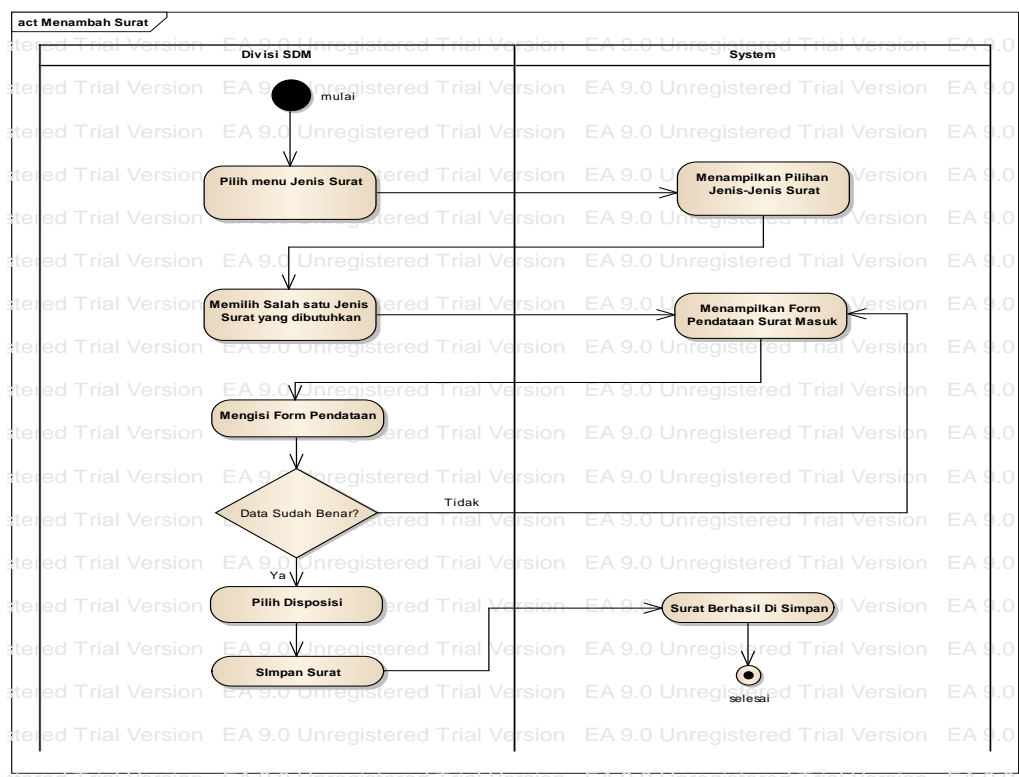

Gambar 4. Activity Diagram Tambah Surat Masuk 
Pada gambar 4 dijelaskan bagaimana staf lembaga menambah data surat masuk untuk disimpan kedalama sistem database serta pemilihan disposisi surat kepada siapa, jika data sudah benar maka Langkah selanjutnya memilih disposisi setelah data benar lalu simpan surat dan sistem akan menyimpan surat kedalam database.

\subsection{Perancangan Sequence Diagram}

Sequence Diagram Sistem Informasi Pendataan Surat Masuk dan Surat Keluar menggambarkan keterkaitan antar objek dan relevansinya terhadap actor-aktor yang terkait dengan system(Rahayu \& Hana, 2016).

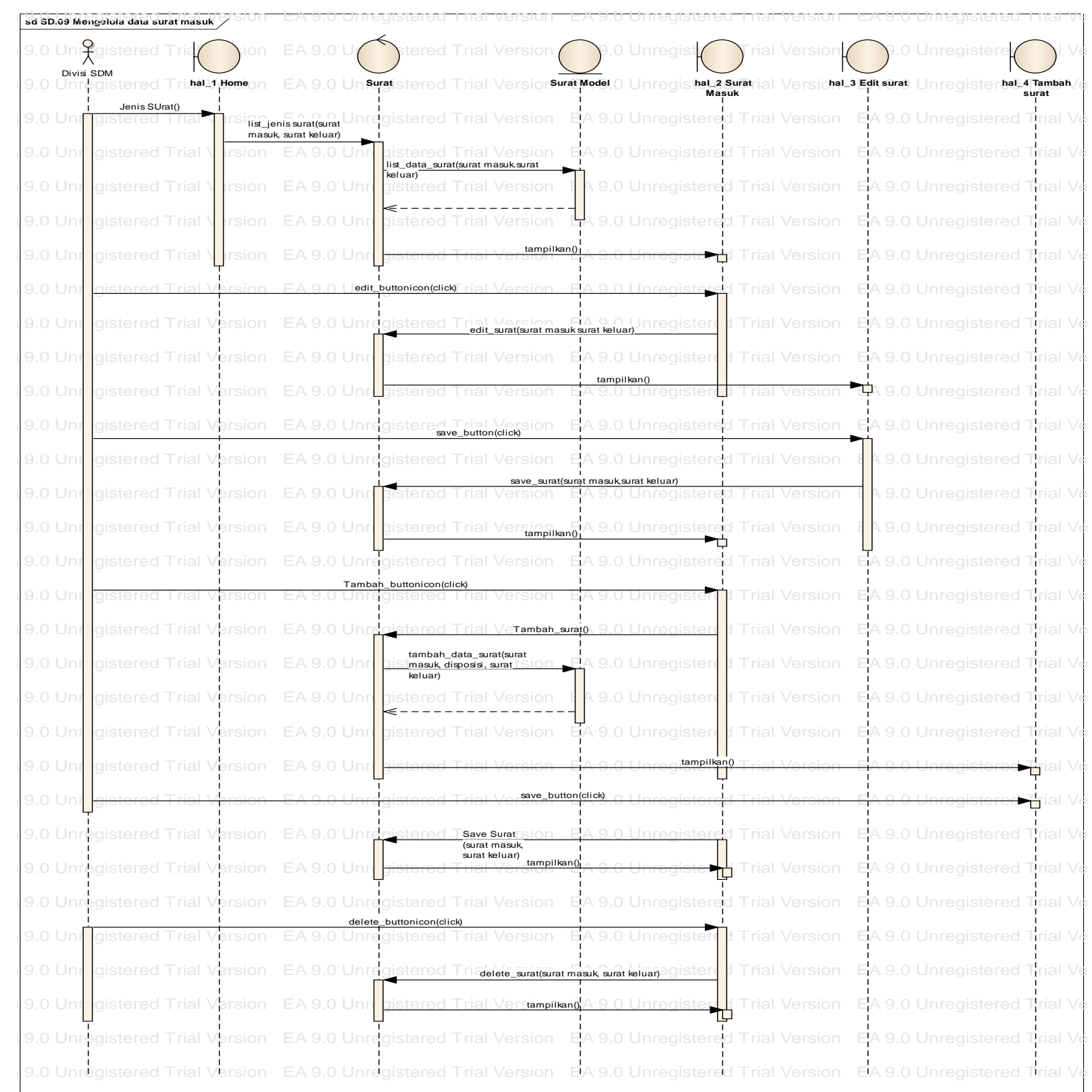

Gambar 5. Sequence Diagram Kelola Data Surat Masuk dan Keluar

\subsection{Perancangan User Interface}

User Interface merupakan bagian yang sangat penting dalam hal untuk meningkatkan kegunaan aplikasi karena merupakan media interaksi manusia dan komputer (Divya et al., 2018). Berikut merupakan tampilan rancangan user interface halaman utama sistem informasi kearsipan pengelolaan surat. 


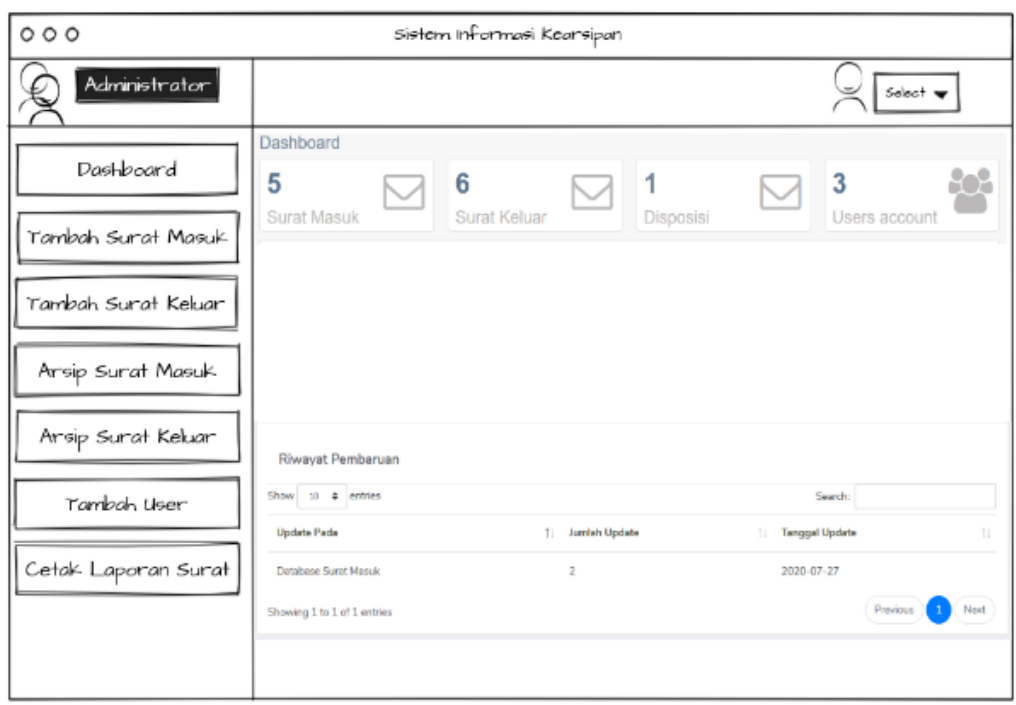

\subsection{Pembahasan}

Gambar 6. Tampilan Halaman Utama

Hasil kegiatan disampaikan terlebih dahulu secara keseluruhan, yang dilanjutkan dengan melakukan proses pembahasan. Pembahasan disajikan secara sistematis dari umum, kemudian mengarah pada yang spesifik. Presentasi hasil dapat dilakukan dengan bantuan tabel, gambar / grafik, peta / rencana, dan skema. Selain itu, hasil dan pembahasan yang disajikan juga saling berhubungan dengan teori yang digunakan:

\subsubsection{Evaluasi}

\section{Pemodelan Proses Bisnis}

Pemodelan proses bisnis berisi pemodelan proses bisnis yang berjalan saat ini dan yang diusulkan. Berikut table 3 menunjukan proses bisnis yang menjadi pokok penelitian.

\section{Tabel 3. Proses Bisnis}

\begin{tabular}{ll}
\hline Kode Proses & \\
\hline PB-1 & Login \\
\hline PB-2 & Melakukan input data surat masuk \\
\hline PB-3 & Memilih disposisi surat \\
\hline PB-4 & Menguload berkas surat masuk \\
\hline PB-5 & Menyimpan hasil input data surat masuk \\
\hline PB-6 & Memasukkan kata kunci ke dalam kolom pencarian \\
\hline PB-7 & Membuka atau melihat arsip \\
\hline PB-8 & Mencetak arsip \\
\hline
\end{tabular}

\section{a. Fitur Sistem}

Pada sistem informasi yang sudah dirancang ada beberapa contoh fitur dari sistem.

Tabel 4. Fitur Sistem

\begin{tabular}{llll}
\hline No & $\begin{array}{r}\text { Kode } \\
\text { Fitur }\end{array}$ & \multicolumn{1}{c}{ Nama Fitur } & \multicolumn{1}{c}{ Deskripsi } \\
\hline $\mathbf{1}$ & F-1 & Login & $\begin{array}{l}\text { Sistem dapat digunakan authentifikasi pada sistem sesuai } \\
\text { username dan password yang dimasukan }\end{array}$ \\
\hline $\mathbf{2}$ & F-2 & $\begin{array}{l}\text { Memasukan data } \\
\text { surat }\end{array}$ & $\begin{array}{l}\text { Sistem dapat digunakan untuk menambah data surat masuk } \\
\text { dan surat keluar }\end{array}$ \\
\hline $\mathbf{3}$ & F-3 & $\begin{array}{l}\text { Mengubah data } \\
\text { surat }\end{array}$ & $\begin{array}{l}\text { Sistem dapat digunakan untuk mengubah atau mengedit } \\
\text { data surat masuk dan surat keluar }\end{array}$ \\
\hline
\end{tabular}




\begin{tabular}{llll}
4 & F-4 & $\begin{array}{l}\text { Menghapus data } \\
\text { surat }\end{array}$ & $\begin{array}{l}\text { Sistem dapat digunakan untuk menghapus data surat masuk } \\
\text { dan surat keluar Ketika sudah tidak dibutuhkan lagi }\end{array}$ \\
\hline $\mathbf{5}$ & F-5 & $\begin{array}{l}\text { Memilih } \\
\text { Disposisi surat }\end{array}$ & Sistem dapat digunakan untuk memilih diposisi surat \\
\hline $\mathbf{6}$ & F-6 & $\begin{array}{l}\text { Mengunggh } \\
\text { arsip surat }\end{array}$ & $\begin{array}{l}\text { Sistem dapat digunakan untuk mengunggah soft copy surat } \\
\text { masuk dan surat keluar serta hasil pemindaan }\end{array}$ \\
\hline $\mathbf{7}$ & F-7 & Menghapus User & $\begin{array}{l}\text { Sistem dapat digunakan untuk menghapus user Ketika } \\
\text { sudah tidak aktif }\end{array}$ \\
\hline
\end{tabular}

\section{b. Persyaratan Fungsional}

Berikut adalah beberapa persyaratan fungsional yang ada di dalam sistem informasi kearsiapan yang akan dirancang.

\begin{tabular}{lllll}
\hline No & $\begin{array}{c}\text { Kode } \\
\text { Fitur }\end{array}$ & $\begin{array}{c}\text { Kode Dasar } \\
\text { Persyaratan } \\
\text { Fungsional }\end{array}$ & $\begin{array}{c}\text { Kode } \\
\text { Lengkap } \\
\text { Persyaratan } \\
\text { Fungsional }\end{array}$ & \multicolumn{1}{c}{ Deskripsi } \\
\hline $\mathbf{1}$ & F-1 & SRS-FU-P1 & SRS-FU-P1-1 & $\begin{array}{l}\text { Sistem dapat digunakan untuk melakukan } \\
\text { login kedalam system }\end{array}$ \\
\hline $\mathbf{2}$ & F-2 & SRS-FU-P2 & SRS-FU-P2-1 & $\begin{array}{l}\text { Sistem dapat digunakan untuk menambah data } \\
\text { surat masuk }\end{array}$ \\
\cline { 4 - 6 } & SRS-FU-P2-2 & $\begin{array}{l}\text { Sistem dapat digunakan untuk menambah data } \\
\text { surat keluar }\end{array}$ \\
\hline $\mathbf{3}$ & F-3 & SRS-FU-P3 & SRS-FU-P3-1 & $\begin{array}{l}\text { Sistem dapat digunakan untuk mengubah data } \\
\text { surat dan melakukan pembaruan }\end{array}$ \\
\hline & SRS-FU-P4 & SRS-FU-P4-1 & $\begin{array}{l}\text { Sistem dapat digunakan untuk menghapus } \\
\text { data arsip surat masuk }\end{array}$ \\
\hline 5 & F-5 & SRS-FU-P5 & SRS-FU-P5-1 & $\begin{array}{l}\text { Sistem dapat digunakan untuk pemilihan } \\
\text { disposisi surat masuk }\end{array}$ \\
\hline
\end{tabular}

\section{c. Persyaratan Non-Fungsional}

Berikut adalah beberapa persyaratan non-fungsional yang ada di dalam sistem informasi kearsiapan yang akan dirancang.

Tabel 6. Persyaratan Non-Fungsional

\begin{tabular}{lcll}
\hline No & Kode & \multicolumn{1}{c}{ Nama } & \multicolumn{1}{c}{ Deskripsi } \\
\hline $\mathbf{1}$ & SRS-NF-P1 & Availability & $\begin{array}{l}\text { Sistem dapat diakses oleh pengguna tanpa jaringan } \\
\text { internet }\end{array}$ \\
\hline $\mathbf{2}$ & SRS-NF-P2 & Usability & $\begin{array}{l}\text { Sistem memiliki User Interface yang mudah di } \\
\text { pahami oleh pengguna }\end{array}$ \\
\hline $\mathbf{3}$ & SRS-NF-P3 & Performance & $\begin{array}{l}\text { Sistem dapat menyediakan kemampuan memberikan } \\
\text { informasi secara real time kepada pengguna }\end{array}$ \\
\hline $\mathbf{4}$ & SRS-NF-P4 & Bahasa Komunikasi & $\begin{array}{l}\text { Sistem menggunakan media Bahasa Indonesia } \\
\text { dalam halaman utamanya dan halaman tampilan } \\
\text { lainnya. }\end{array}$ \\
\hline
\end{tabular}




\section{d. Traceability Matrix}

Traceability matrix digunakan untuk menelusuri hasil dari analisis persyaratan dan rancangan yang telah dibuat. Berikut beberapa hasil dari evaluasi yang telah diusulkan.

Tabel 7. Traceability Matrix

\begin{tabular}{|c|c|c|c|c|c|}
\hline $\begin{array}{c}\text { Kode } \\
\text { Aktivitas } \\
\text { BPMN }\end{array}$ & $\begin{array}{c}\text { Kode } \\
\text { Persyaratan } \\
\text { Fungsional }\end{array}$ & $\begin{array}{c}\text { Kode Use } \\
\text { Case }\end{array}$ & Nama Use Case & $\begin{array}{c}\text { Kode } \\
\text { Diagram } \\
\text { Sequence }\end{array}$ & $\begin{array}{c}\text { Kode User } \\
\text { Interface }\end{array}$ \\
\hline PB-1 & SRS-FU-P1-1 & UC1 & Login & SD-01 & UI-01 \\
\hline PB-2 & $\begin{array}{l}\text { SRS-FU-P2-1, } \\
\text { SRS-FU-P2-2 }\end{array}$ & $\mathrm{UC} 2$ & $\begin{array}{l}\text { Mengelola Data } \\
\text { Surat Masuk }\end{array}$ & SD-02, SD-03 & UI-02, UI-03 \\
\hline PB-3 & $\begin{array}{l}\text { SRS-FU-P3-1, } \\
\text { SRS-FU P3-2 }\end{array}$ & $\mathrm{UC} 2$ & $\begin{array}{l}\text { Mengelola Data } \\
\text { Surat Keluar }\end{array}$ & SD-04, SD-05 & UI-04, UI-05 \\
\hline PB-4 & $\begin{array}{l}\text { SRS-FU-P5-1, } \\
\text { SRS-FU-P5-2 }\end{array}$ & UC3 & $\begin{array}{l}\text { Mencari Arsip } \\
\text { Surat }\end{array}$ & SD-06, SD-07 & UI-06 \\
\hline PB-5 & SRS-FU-P7-1 & UC5 & $\begin{array}{l}\text { Mendaftarkan User } \\
\text { kedalam sistem }\end{array}$ & SD-08, SD-09 & UI-07 \\
\hline PB-6 & SRS-FU-P4-1 & UC6 & $\begin{array}{l}\text { Melihat Laporan } \\
\text { surat masuk }\end{array}$ & SD-11 & UI-11 \\
\hline
\end{tabular}

\section{e. Tinjauan Traceability}

Tinjauan traceability yang dilakukan oleh peneliti berdasarkan traceability yang sudah dilakukan.

Tabel 8. Tinjauan Traceability

\begin{tabular}{lllll}
\hline No & \multicolumn{1}{c}{ Pertanyaan } & YA & Tidak & \multicolumn{1}{c}{ Keterangan } \\
\hline $\mathbf{1}$ & $\begin{array}{l}\text { Apakah setiap persyaratan } \\
\text { sudah didefinisikan dengan } \\
\text { benar dan unik? }\end{array}$ & $\checkmark$ & $\begin{array}{l}\text { Setiap persyaratan sudah didefinisikan } \\
\text { dengan benar dan memiliki kode unik } \\
\text { dengan kombinasia angka dan huruf }\end{array}$ \\
\hline $\mathbf{2}$ & $\begin{array}{l}\text { Apakah setiap persyaratan } \\
\text { fungsional sistem dapat } \\
\text { dilacak sampai persyaratan } \\
\text { tingkat tinggi? (seperti use } \\
\text { case) }\end{array}$ & $\checkmark$ & $\begin{array}{l}\text { Setiap persyaratan fungsional dari } \\
\text { sistem dapat dilacak sampai tingkat } \\
\text { tinggi dibuktikan dengan tabel } \\
\text { traceability matrix }\end{array}$ \\
\hline $\mathbf{3}$ & $\begin{array}{l}\text { Apakah semua rancangan } \\
\text { User Interface dapat dilacak } \\
\text { Kembali sesuai pesyaratan? }\end{array}$ & $\checkmark$ & $\begin{array}{l}\text { Semua bagian rancangan User } \\
\text { persyaratan dibuktikan dengan tabel } \\
\text { traceability matrix }\end{array}$ \\
\hline
\end{tabular}

\section{KESIMPULAN}

Pada Pemodelan proses bisnis yang dilakukan di penelitian ini mencakup proses bisnis yang berjalan Saat ini dan proses bisnis usulan. Terdapat 10 perubahan aktivitas pada proses bisnis usulan dan pengelolaan arsip surat sudah tidak lagi dilakukan secara manual, melainkan sudah menggunakan aplikasi pengelolaan arsip data surat yang lebih terkomputerisasi dan lebih efisien dalam hal pencarian data surat juga penyimpanan arsip surat tidak gampang rusak. Hasil analisis persyaratan penelitian mencakup 19 fitur yang terdiri dari 15 persyaratan fungsional dan 4 persyaratan nonfungsional, untuk hasil rancangan sistem informasi pengelolaan pengarsipan surat pada Lembaga B terdiri dari arsitektur sistem diantaranya analisis use case, activity diagram, sequence diagram dan juga desain user interface. Hasil evaluasi menggunakan traceability semua perancangan sistem sudah memenuhi semua persyaratan dan dapat dilacak kembali. Bagi penelitian selanjutnya, hasil penelitian ini bisa digunakan sebagai media refrensi untuk penelitian. Rancangan sistem informasi ini 
diharapkan bisa dikembangkan lagi dengan menambahkan lebih banyak fitur, persyaratan fungsional serta perysaratan non-fungsional agar lebih detail untuk dibangun sebuah sistem informasi pengelolaan pengarsipan surat berbasis website.

\section{UCAPAN TERIMAKASIH}

Ucapan terimakasih saya sampaikan kepada pihak Lembaga BS yang sudah mengizinkan untuk melakukan penelitian, serta ibu Ambarwati yang sudah berkontribusi dalam penulisan artikel jurnal ini.

\section{DAFTAR PUSTAKA}

Dewati, C., Aknuranda, I., \& Putra, W. (2019). Analisis dan Perancangan Sistem Informasi Pengarsipan Dokumen Dengan Pendekatan Berorientasi Objek (Studi Kasus : Dinas Sekretariat Dewan, Pemerintahan Kota Batu). 3(5), 5140-5146.

Divya, K. S., Bhargavi, P., \& Jyothi, S. (2018). User Interface Design Issues for Easy and Efficient Human Computer Interaction: An Explanatory Approach. International Journal of Computer Sciences and Engineering Open Access Machine Learning Algorithms in Big Data Analytics, October, 157-166. https://doi.org/10.26438/ijcse/v6i1.6370

Esparteiro Garcia, J., \& C. R. Paiva, A. (2016). A Requirements-to-Implementation Mapping Tool for Requirements Traceability. Journal of Software, 11(2), 193-200. https://doi.org/10.17706/jsw.11.2.193-200

Hatta, M., Anwar, M. M., Diana, I. N., \& Amarul M, M. H. (2019). Perancangan Sistem Informasi Pengarsipan Dan Disposisi Surat Berbasis Web Dengan Menggunakan Framework Codeigniter. SCAN - Jurnal Teknologi Informasi Dan Komunikasi, 14(2), 8-12. https://doi.org/10.33005/scan.v14i2.1481

Irmawati, D., \& Indrihapsari, Y. (2014). Sistem Informasi Kearsipan untuk Meningkatkan Kualitas Pelayanan. Jurnal Pendidikan Teknologi Dan Kejuruan, 22(2), 136-147. https://doi.org/10.21831/jptk.v22i2.8947

Mahmudah, S., Widiastuti, L., \& Ernawati, S. (2019). Sistem Informasi Manajemen Pengarsipan Surat Masuk Dan Surat Keluar (Studi Kasus : Ma Darul Ihya Bogor). Jurnal Media Informatika Budidarma, 3(3), 225-231. https://doi.org/10.30865/mib.v3i3.1215

Qonita, A., Rachmadi, A., \& Rusdianto, D. S. (2018). Analisis dan Perancangan Sistem Informasi Pengelolaan Mutabaah Siswa ( Studi Kasus: Pendidikan Al- Qur' an di SDIT Madani Ekselensia Sidoarjo ). Jurnal Pengembangan Teknologi Informasi Dan Ilmu Komputer (JPTIIK) Universitas Brawijaya, 2(12), 6922-6929.

Rahayu, S., \& Hana, D. (2016). Sistem Informasi Pendataan Surat Masuk dan Surat Keluar Pada SMK Negeri 5 Tangerang. Eksplora Informatika, 5(2), 138-147. https://eksplora.stikombali.ac.id/index.php/eksplora/article/view/84/67

Safitri, L. N., Wicaksono, S. A., \& Saputra, M. C. (2018). Analisis dan Perancangan Sistem Informasi Manajemen Pusat Laktasi : Lactashare. Jurnal Pengembangan Teknologi Informasi Dan Ilmu Komputer (J-PTIIK) Universitas Brawijaya, 2(6), 2286-2294.

Setiawan, F., \& Yanuarti, E. (2016). Analisa dan Perancangan Sistem Informasi Pengarsipan Berkas Pertanggungjawaban Anggaran APBD pada Dinas Pemuda dan Olahraga Provinsi Kepulauan Bangka Belitung. Jurnal Sisfokom (Sistem Informasi Dan Komputer), 5(1), 1. https://doi.org/10.32736/sisfokom.v5i1.192 